\title{
Discussion: Assessing the potential value of bridge monitoring systems
}

Paul J. Vardanega BE, MEngSc QIdUT, PhD Cantab, MASCE, MIEAust, FHEA

Lecturer in Civil Engineering, Department of Civil Engineering, University of Bristol, Bristol, UK

Graham T. Webb MEng, MA, PhD Cantab

Engineer, WSP I Parsons Brinkerhoff, London, UK; Formerly Doctoral Student, Department of Engineering, University of Cambridge, Cambridge, UK

Paul R. A. Fidler MA Cantab

Computer Associate, Department of Engineering, University of Cambridge, Cambridge, UK

\section{Contribution by John Collins}

The work of Vardanega et al. (2016) on assessing the potential value of bridge monitoring systems is a much needed paper given the growing interest in structural health monitoring (SHM) afforded by this era of big data. The contributor urges anyone considering how SHM systems should be appraised for use on bridges to read it. Of the guidance made, Figure 1 is particularly valuable, with the authors' important observation that

\footnotetext{
... the choice of technology itself... is a much later consideration compared with the more high-level considerations of 'why', 'where', 'what' and 'for whom'
}

This contributor was also glad to see reference made to serendipity in Section 3.3. Whilst a clear known reason must be made for installation of SHM, it should also be recognised that data have potential for use in unforeseeable and interesting ways. This opens up a further area which the contributor has not yet seen discussed with regard to SHM data on bridges: open publishing of raw datasets to see how the wider engineering community might interpret data or find use in them. Anyway, specific queries sit under Figure 1's interrogatives, and it would be most interesting to hear the authors' thoughts.

The 'why' is vital. Could this be expanded upon such that a structural engineer defines the root structural question they are looking to answer? For example, at this stage, a structural engineer should not be stating 'I want to know the strain at this location' but asking 'what is the load effect for at this location?'.

Under 'what', could it be stressed that existing structures will have pre-existing damage? If the exact state of degradation is to be identified, the level of deterioration needs to first be determined. An excellent example is the need for intrusive
Campbell R. Middleton BE(Hons) Tas, MSc DIC Lond, PhD Cantab, FICE, MIEAust, CEng, CPEng

Laing O'Rourke Professor of Construction Engineering, Department of Engineering, University of Cambridge, Cambridge, UK

John Collins MEng(Hons), CEng, MICE

Senior Engineer, Bridges \& Civil Structures, Arup, Leeds, UK inspection to suspension bridge cables to identify wire breaks, before commencing acoustic monitoring (e.g. Cocksedge et al., 2010).

\section{Authors' reply}

The authors thank Mr Collins for his encouraging and constructive comments about the paper and are pleased to make the following reply.

The paper under discussion (Vardanega et al., 2016) proposes an assessment philosophy and methodology that it is hoped others may try in a design/consultancy setting and then propose modifications for the future.

Regarding serendipity: a carefully collected dataset that is accessible and future-proofed may indeed yield value to an asset owner at some later date. The costs of installation of a monitoring system and ongoing data collection and storage need to be borne by someone and the question is whether it can be argued that a future serendipitous benefit (that may or may not occur) is a good use of resources.

The authors completely agree that monitoring datasets that have been suitably filtered and audited should be made available, ideally on an open-access basis. This could allow for improvements to model calibration efforts that can be hampered by a lack of data and could also stimulate innovative new approaches to extracting value using modern data analytics and signal processing technology. It is essential that the data (whether open-access or not) be future-proofed and this remains a key concern for those managing bridge assets (cf. Masood et al., 2016).

The 'why' is indeed vital! This is often overlooked in the push to install a monitoring system with the aim of creating a 
'smart' structure. The authors agree that, for example, simply knowing a strain at a point on an existing bridge is of little value unless it can be tied to a question that relates to the behaviour of the structure itself or the material from which it is constructed. It is also worth remembering that structural engineers are not the only stakeholders who may be able to benefit from the information obtained from a monitoring system. Information to assist with purely operational decisions may be equally valuable to owners or managers.

The authors also agree that all structures are likely to have some pre-existing damage. Not every bridge that is built will be loaded as expected or built exactly as specified. Damage might be defined as 'any deviation from the design state'. Bridge engineers still rely heavily on visual inspections and assessments to determine the extent and presence of 'damage' (e.g. Bennetts et al., 2016; Canning and Kashani, 2016; Lea and Middleton, 2002). Detecting that some unknown damage is present is still difficult, even with a visual inspection. The example reported by Cocksedge et al. (2010) is a good illustration of this and also shows that monitoring systems in remote locations used to track the rate of progression of damage can add value.

Clearly it is important to know what it is you are trying to measure or monitor before you start, hence the relevance and importance of the classification system proposed by Webb et al. (2015). This enables the SHM consultant to identify the possible reasons why an SHM system may deliver value to different stakeholders. Monitoring endeavours do not have to be long-term concerns, for example, a short-term monitoring installation may provide valuable information to assist with identifying existing damage and helping to specify an appropriate long-term monitoring programme for the particular problem.

Using monitoring and model updating to determine changes of the 'reserve capacity' of bridge structures (Pasquier and Smith, 2016; Smith, 2015) is another use of SHM that falls within the 'model validation' category proposed by Webb et al. (2015).

\section{Acknowledgements}

The first author thanks his colleague Dr Mark Schenk for helpful suggestions while preparing this reply.

\section{REFERENCES}

Bennetts J, Vardanega PJ, Taylor CA and Denton SR (2016)

Bridge data - what do we collect and how do we use it? In Transforming the Future of Infrastructure through Smarter Information: Proceedings of an International Conference on Smart Infrastructure and Construction (Mair RJ, Soga K, Jin Y, Parlikad AK and Schooling JM (eds)). ICE Publishing, London, UK, pp. 531-536.

Canning L and Kashani MM (2016) Assessment of U-type wrought iron railway bridges. Proceedings of the Institution of Civil Engineers - Engineering History and Heritage 169(2): 58-67, http://dx.doi.org/10.1680/ jenhh.15.00017.

Cocksedge C, Hudson T, Urbans B and Baron S (2010) M48 Severn Bridge - main cable inspection and rehabilitation. Proceedings of the Institution of Civil Engineers - Bridge Engineering 163(4): 181-195, http:/dx.doi.org/10.1680/ bren.2010.4.181.

Lea FC and Middleton CR (2002) Reliability of Visual Inspection of Highway Bridges. Department of Engineering, University of Cambridge, Cambridge, UK, Technical Report CUED/DSTRUCT/TR.201.

Masood T, Yilmaz G, McFarlane DC et al. (2016) Information future-proofing assessment for infrastructure assets. In Transforming the Future of Infrastructure through Smarter Information: Proceedings of an International Conference on Smart Infrastructure and Construction (Mair RJ, Soga K, Jin Y, Parlikad AK and Schooling JM (eds)). ICE Publishing, London, UK, pp. 557-562.

Pasquier R and Smith IFC (2016) Iterative structural identification framework for evaluation of existing structures. Engineering Structures 106: 179-194.

Smith IFC (2015) Grand challenges of structural sensing. Frontiers in Built Environment 1: 19, http://dx.doi.org/ 10.3389/fbuil.2015.00019.

Vardanega PJ, Webb GT, Fidler PRA and Middleton CR (2016) Assessing the potential value of bridge monitoring systems. Proceedings of the Institution of Civil Engineers - Bridge Engineering 169(2): 126-138, http://dx.doi.org/ 10.1680/jbren.15.00016.

Webb GT, Vardanega PJ and Middleton CR (2015) Categories of SHM deployments: technologies and capabilities. Journal of Bridge Engineering ASCE 20(11): 04014118. 